\title{
The Implementation of HOTS-Based PPKn Learning at SMAN 1 Solok Selatan
}

\author{
Ewi Herlina ${ }^{1)}$, Maria Montessori ${ }^{2)}$ \\ Masters Study Programs Pancasila and civic education, Faculty of Social Science Universitas Negeri \\ Padang, Indonesia ${ }^{1,2}$ \\ ewiherlina20@gmail.com
}

\begin{abstract}
This article aims to analyze the implementation of HOTS-based PPKn learning at SMAN 1 Solok Selatan and identify supporting and inhibiting factors for HOTS-based PPKn learning at SMAN 1 Solok Selatan and describe the HOTS-based PPKn learning design at SMAN 1 Solok Selatan. The study of the problem and the focus of this research is about Learning Guidance by Pancasila and Citizenship Education Teachers at SMAN 1 Solok Selatan. To Improve Students' High Level Thinking Ability, the research was conducted through a qualitative approach, to obtain in-depth and holistic research results. Qualitative research in this case intends to explore the meaning of the behavior behind human action, in qualitative research the researcher is the main instrument of data collection. The qualitative method is used because it reveals how the teacher's coaching in HOTS-based PPKn learning. The findings in the study revealed that HOTS-based PPKn learning had been implemented which had previously been designed in the learning implementation plan. The HOTS learning implementation learning design had been systematically compiled in the Learning Implementation Plan. HOTS-based PPKn learning is strongly supported by school policies in giving freedom to teachers in determining learning strategies / methods that are in accordance with the learning facilities used in competency attainment as measured through HOTS-based learning evaluations.
\end{abstract}

Keywords: Development, Learning, Pancasila and Citizenship Education, HOTS

\begin{abstract}
Abstrak. Artikel ini bertujuan untuk menganalisis pelaksanaan Pembelajaran PPKn Berbasis HOTS di SMAN 1 Solok Selatan dan mengidentifikasi Faktor pendukung dan penghambat Pembelajaran PPKn Berbasis HOTS di SMAN 1 Solok Selatan serta mendeskripsikan desain pembelajaran PPKn berbasis HOTS di SMAN 1 Solok Selatan. Kajian masalah dan fokus penelitian ini tentang Pembinaan Pembelajaran Oleh Guru Pendidikan Pancasila dan Kewarganegaraan di SMAN 1 Solok Selatan Untuk Meningkatkan Kemampuan Berfikir Tingkat Tinggi Siswa maka penelitian dilakukan melalui pendekatan kualitatif, untuk mendapatkan hasil penelitian secara mendalam dan holistik. Penelitian kualitatif dalam hal ini bermaksud menggali makna perilaku yang berada dibalik tindakan manusia, dalam penelitian kualitatif peneliti sebagai instrument utama pengumpulan data. Metode kualitatif digunakan karena mengungkapkan bagaimana pembinaan yang dilakukan guru dalam pembelajaran PPKn berbasis HOTS. Temuan dalam penelitian mengungkapkan bahwa pembelajaran PPKn berbasis HOTS telah diterapkan yang sebelumnya telah di rancang dalam rencana pelaksanaan pembelajaran, Desain pembelajaran pelaksanaan pembelajaran HOTS telah disusun secara sistematis dalam Rencana Pelaksanaan Pembelajaran. Pembelajaran PPKn berbasis HOTS sangat didukung oleh kebijakan sekolah dalam memberikan kebebasan terhadap guru dalam menentukan strategi/metode pembelajaran yang sesuai dengan fasilitas belajar yang digunakan dalam ketercapaian kompetensi yang diukur melalui evaluasi belajar yang berbasis HOTS.
\end{abstract}

Kata Kunci: Pembinaan, Pembelajaran, Pendidikan Pancasila dan Kewarganegaraan, HOTS 


\section{INTRODUCTION}

This higher-order thinking skill requires a person to apply new information or previous knowledge and manipulate information to reach possible answers in new situations. Therefore, higher-order thinking skills are defined as the use of the mind widely to find new challenges (Filsaime: 2008).

Talking about the stages of thinking, Bloom's taxonomy is considered the basis for higher-order thinking, this thinking is based on that some types of learning require more cognitive processes than others, but have more general benefits (Heong, et al. 2011). Based on Bloom's thinking, there are three aspects of the cognitive realm that are part of the higherorder thinking ability. The three aspects are the analyzing aspect (C4), the evaluating aspect (C5) and the creating aspect (C6). Meanwhile, three other aspects in the same realm, namely the aspect of remembering $(\mathrm{C} 1)$, the aspect of understanding (C2), and the aspect of applying (C3), are included in the lower-order thinking intellectual section.

Anderson and Krathwohl revised Bloom's taxonomy from one dimension into two dimensions, namely the cognitive process dimension and the types of knowledge dimension. The cognitive process dimension is the result of a revision of Bloom's taxonomy. Anderson classified cognitive processes into six categories, namely remembering, understanding, applying, analyzing, evaluating, and creating (Krathwohl \& Andrerson, 2015).

A common theme in higher-order thinking movements is thinking skills that involve the ability to make reasoned decisions in complex situations. This movement emphasizes "knowing how" rather than "knowing what". Therefore, efforts to help individuals acquire these abilities require selfawareness as part of the efforts of educators to explore higher-order thinking skills by utilizing methods rather than the simple role of memorization and dictate teaching.

By looking at the current reality, highorder thinking skills are very important to be applied in various aspects of knowledge and subjects, including in PPKn subjects. Specifically, the PPKn objectives in the 2013 Curriculum contain all these dimensions so that students are able to:

1. Displaying a character that reflects the personal and social appreciation, understanding and practice of Pancasila values and morals;

2. Having a constitutional commitment that is supported by a positive attitude and a complete understanding of the 1945 Constitution of the Republic of Indonesia;

3. Think critically, rationally, and creatively and have a spirit of nationalism and love for the country which is imbued with the values of Pancasila, the 1945 Constitution of the Republic of Indonesia, the spirit of Unity in Diversity, and the commitment of 
the Unitary State of the Republic of Indonesia, and

4. To participate actively, intelligently, and responsibly as members of society, as a nation, and as citizens of the state according to their dignity and status as creatures of the Almighty God who live together in various socio-cultural structures.

Based on the objectives of PPKn in learning curriculum 2013 in points 3 and 4, it is quite clear to us that the need for developing high-level thinking skills of students, especially in PPKn learning. High-order thinking skills are very important to be instilled in students through PPKn learning considering that the challenges of improving quality in various aspects of life are nonnegotiable. The rapid development of science and technology and the pressure of globalization which eliminates boundaries between countries, requires each individual to exert his / her mind and all his / her potential to be able to survive and be able to win the competition in seizing opportunities at various levels of thinking for each level of education according to the 2013 curriculum.

This is following the results of Asnawi's (2017) research which also found that the application of the scientific approach in the 2013 curriculum to Civics learning has shown a positive impact in developing HOTS on several aspects of student citizenship skills, especially in the aspects of answering, asking, discussing, and participating skills. active. In other words, it can be understood that a teacher must have the ability for cognitive aspects to be able to develop students' thinking abilities. In another study, Wahidmurni (2018) states that a teacher must have the ability to understand the level of cognitive aspects along with the description of $\mathrm{KKO}$ in competency achievement indicators, and prove it in compiling test instruments, especially in the form of questions that measure higher-order thinking skills / questions

A different thing is found at SMAN 1 South Solok Regency which is a favorite school with superior graduates and various achievements in both academic and nonacademic fields. Even so, in the learning process there were still students who did not understand the PPKn learning material, because it was difficult for students to connect the material with national and state life.

This is evidenced by the frequency with which students do not meet the KKM in the PPKn Daily Test Assessment compared to exact subjects such as physics, mathematics, etc. The results of the observations show that in the last few years on the PPKn daily assessment, it was difficult for students to fulfill the KKM 80 especially when the daily test questions were in the form of essays. Meanwhile, at the end of the semester to the final school examination students can fulfill the KKM with multiple choice questions (objective). 
This shows that the low level of critical thinking of students in the learning process, and the low level of solving essay questions for students because it requires highorder thinking power. Thus, the conditions indirectly require that PPKn learning be directed at increasing thinking skills to compete in global competition. Starting from the preparation of learning tools consisting of lesson plans, worksheets to description questions (essays) and the PPKn learning process which can improve the quality of learning more effectively, efficiently, fun, and meaningfully, to increase the quality of achievement of learning outcomes and promote high-level thinking students. (not just conveying facts). Related to the above problems, this article continues How to Implement HOTS-Based PPKn Learning at SMAN 1 Solok Selatan?

\section{RESEARCH METHODS}

This article was the result of a study of a qualitative approach, to obtain in-depth and holistic research results. This was under the opinion of Sudjana (2008: 72) which states that qualitative research is a form of research approach aimed at describing or describing existing phenomena, whether phenomena of events, social activities, attitudes, beliefs, perceptions, thoughts of people individually or groups that are natural or human engineering.

The location of the research was carried out at SMA Negeri 1 Solok Selatan,
Solok Selatan Regency, West Sumatra Province by determining informants through purposive sampling method. Meanwhile, the research data collection technique was carried out using interviews, observation and documentation. To test the credibility of the data, it was done by checking the data that had been obtained through the source triangulation technique. Then the data was analyzed and then described and categorized which data was the same, which was different and which was specific from some of these data sources. The data that been analyzed produces a conclusion which is asked for an agreement (member check) with some of these data sources (Sugiyono, 2013: 370).

\section{DISCUSSION}

One of the elements of change in the 2013 curriculum is the strengthening of an effective, efficient, fun, and meaningful learning process, to improve students' higherorder thinking skills (HOTS).

In fact, the results of research at SMAN 1 Solok Selatan show that PPKn teachers still do not understand HOTS learning. This can be seen at the learning planning stage that the teacher does not carry out the analysis of KI / KD, indicators and learning objectives but only uses the KI / KD analysis, indicators, objectives, and learning and assessment activities that have been designed by the MGMP so that the indicators of competency achievement listed are not 
analyzed. and developed according to student needs.

Ahmad (2016) revealed that teachers should be able to develop and convert from learning that is still Lower Order Thinking Skill (LOTS) to Higher Order Thinking Skill (HOTS), and this must have started since designing the Learning Implementation Plan (RPP).

The form of a lesson plan is a Learning Implementation Plan (RPP). Through RPP, teachers can determine the things that are needed so that the desired goals can be achieved (Bararah, 2017). The lesson plan should include a complete learning scenario with the methods used to achieve learning objectives accompanied by activities undertaken to achieve these goals. So in this case the HOTS Learning Characteristics should be described in the planning stage.

Therefore, learning planning must be structured into a system or process of learning students that is systematically designed, implemented and evaluated so that students can achieve the expected learning objectives. Learning planning has several components, including learning objectives, learning materials, learning strategies and methods, learning media, and learning evaluation. Learning processes input to produce the desired output (Al Hadad: 2012).

According to Akhlan and Rahman (1997: 15), learning planning includes:

1. What objectives are to be achieved
2. Teaching materials;

3. Teaching and learning process; and

4. Assessment tools.

Learning planning includes these four elements as an important factor in determining the initial steps in implementing learning planning in the classroom. The learning objectives made by the teacher as a standard for achieving competence in the teaching and learning process.

This is because learning materials are used as a means to achieve learning objectives in the teaching and learning process and support learning activities carried out by teachers and students based on learning objectives that have been previously made by the teacher and in practice the teacher also prepares supporting tools used to measure the achievement of learning objectives. already made.

According to Akhlan and Rahman (1997: 7), the characteristics of good teaching planning should contain the following principles.

1. Developing good interaction relationships among humans, in this case, students and teachers as well as related personalities.

2. Is a vehicle or a place to develop all the potential that exists and is owned by students.

3. Having an objective attitude of ratio (appropriate and reasonable), comprehensive and systematic (comprehensive and neatly arranged). 
4. Controlling one's strength, not based on the strength of others,

5. Supported by facts and data that support the achievement of the goals that have been formulated.

6. Flexible and dynamic, meaning that it is easy to adapt to conditions and developments towards a better and more advanced direction.

Each lesson is preceded by the creation of a teaching plan that includes an annual program, semester and teaching preparation. The teaching plan is based on the syllabus and is adjusted to the applicable educational calendar, schedule of ongoing subjects and available facilities.

Designing lesson plans, which was carried out by teachers of SMAN 1 Solok Selatan, was not the result of the formulation of the teacher who taught, but the formulation of the lesson plan compiled by the MGMP. The planning of the teaching and learning process if compiled by the teacher who teaches is a factor that supports the conditions of learning in the classroom which contains a series of definitions of teaching and learning events carried out by a group of students, including the development of HOTS-based learning.

In this connection, the teacher planning in implementing the teaching and learning process is as follows:

1. Instructional planning.

2. Learning organization.
3. Directing students.

4. Supervision and controlling.

5. Assessment research. (Akhlan and Rahman, 2007: 16)

Referring to some of the points above, the results of the research findings show that the lesson planning carried out by the PPKn teacher at SMAN 1 Solok Selatan has not adjusted to the principles of preparation in the RPP. The results also showed that the lesson plans compiled did not fulfil the HOTS learning planning. In connection with this, Siti (2016) revealed that several steps must be prepared in the development of HOTS-based PPKn learning, namely: a) Effective Day Analysis and Learning Program analysis b) Creating an Annual Program, Semester Program and Billing Program c) Prepare a Syllabus d) Develop a Learning Plan e) Learning Assessment Learning development that pays attention to higher-order thinking skills must pay attention to the stages of thinking according to Bloom's taxonomy, starting from remembering, understanding, applying, analyzing, evaluating, and creating. The findings of these previous studies show that the development of learning tools, both related to developing strategies, teaching materials, and media can motivate students to think more critically and be able to increase learning activities and learning outcomes, so that learning runs more effectively, efficiently, and fun. 


\section{CONCLUSION}

The implementation of HOTS-based PPKn learning at SMAN 1 Solok Selatan is emphasized in the core learning activities where the teacher implements the model or strategy that has been predetermined in the RPP. Before implementing the learning, the teacher analyzes the Basic Competence (KD) and translates it into a GPA in the lesson plan, then determines what tools, materials, media, and learning resources they will use, as well as what test instruments they will use.

The implementation of HOTS learning must be arranged systematically in a Learning Implementation Plan (RPP), carried out in learning, then assessed based on the previously determined Competency Achievement Indicators (GPA). The questions given are not only concerned with low-level cognitive (Lower Order Thinking Skills / LOTS) such as knowing (C-1), understanding (C-2), and applying (C-3), but also leading to cognitive levels. high (Higher Order Thinking Skills / HOTS) such as analyzing (C-4), evaluating (C-5), and creating (C-6). HOTS learning provides a stimulus that is relevant to the material being studied by students. The stimulus becomes an introduction as well as stimulates the critical thinking skills of students to solve problems. Through HOTS learning, students can find and construct meaning from the material they are learning.

\section{REFERENCES}

[1] Asnawi, T.M. Jamil (2017). Seminar Aanalisis Penerapan Pendekatan Saintifik pada

[2] Dian Kurniati, (2016). Kemampuan Berpikir Tingkat Tinggi Siswa SMP di Kabupaten Jember dalam Menyelesaikan soal Berstandar pisa. Jurnal Penelitian dan Evaluasi Pendidikan Volume 20, No 2, Desember 2016 (142-155

[3] Dian Utama Wati, (2013). Menngkatkan Kemampuan Berpikir Kreatif Siwa dalam Mata Pelajaran PPKn di SMP Negeri 2 Lamongan. Kajian Moral dan Kewarganegaraan No 1 Vol 1.

[4] Edi Kusnadi \& Diny Fitriyani, (2015). Model Pembelajaran Pembentukan Konsep untuk mengembangkan Keterampilan Berpikir Kritis dalam Pembelajaran Pendidikan Kewarganegaraan. Volume 2 No. 01 Juni 2015 /ISSN 2460-1802

[5] Etika Prasetyani, Yusuf Hartono, dan Ely Susanti, (2016). Kemampuan Berpikir Tingkat Tinggi Siswa di SMA Negeri 18 Palembang. JURNAL GANTANG Pendidikan Matematika FKIP - UMRAH Vol. 1 No. 1, Agustus 2016, p-ISSN. 2503-[1] 0671, e-ISSN. 2548-5547.

[6] Filsaime, DK. (2008). Menguak Rahasia Berpikir Kritis \& Kreatif. Jakarta: Prestasi Pustaka.

[7] Harry Yusmanto, (2017). The Application of Carousel Feedback and Round Table CooperativeLearning Models to Improve Student's Higher Order Thinking Skill(HOTS) and Social Studies Learning Outcomes. International Education Studies; Vol. 10, No. 10; 2017 ISSN 1913-9020 E-ISSN 1913-9039

[8] Kus Andini Purbaningrum, (2017). Kemampuan Berpikir Tingkat Tinggi Siswa SMP Dalam Pemechan Masalah Matematika ditinjau Dari Gaya Belajar. JPPM Vol. 10 No. 2

[9] Kanji, H., Nursalam, N., Nawir, M., \& Suardi, S. (2019). Evaluasi Integrasi Pendidikan Karakter dalam Pembelajaran Ilmu Pengetahuan Sosial di Sekolah Dasar. JED (Journal of Etika Demokrasi), 4(2). 
[10] Lewy1, Zulkardi, Nyimas Aisyah. (201)2. Pengembangan Soal Untuk Mengukur Kemampuan Berpikir Tingkat Tinggi. Jurnal Pendidikan, VOLUME 3.NO.2,

[11] Maria Montessori, (2002). Pendidikan Kewarganegaraan dan Keterampilan Berpikir. Demokrasi Vol.I No.1

Pembelajaran PKn untuk meningkatkan Kecakapan Kewarganegaraan siswa SD, Forum Rapimnas PascaSarjana, Banda Aceh,0000-00-00

http://pps.unsyiah.ac.id/forpimpas-barat/

[12] Suyono, (2010). Pengaruh Pengunaan Strategi Pembelajaran terhadap Hasil Belajar PPKn di SMPN Gedangan Sidoarjo Tahun VI, No. 11

[13] Suardi, S., Herdiansyah, H., Ramlan, H., \& Mutiara, I. A. (2019). Implementasi Pendidikan Karakter Melalui Mata Pelajaran Pendidikan Kewarganegaraan di SMA Jaya Negara Makassar. JED (Journal of Etika Demokrasi), 4(1).

[14] Trisnawati, (2018). Influence Of Contextual Teaching Learning (CTL) Learning Model and Critical Thinking ON THE Learning Results of Civic Education for 7th Grade Students of Imelda School Medan School Year . IOSR Journal of Research \& Method in Education (IOSR-JRME) e-ISSN: 2320 7388,p-ISSN: 2320-737X Volume 7, Issue 5 Ver. VI (Sep. - Oct. 2017), PP 25-31 www.iosrjournals.org

[15] Winarti, (2015). Implementasi Pendekatan Terhadap Kemampuan Berpikir Kritis Siswa. Jurnal Penelitian dan Pendidikan IPS (JPPI) Volume 9 No 3 (2015) 1318-1327 ISSN (Print): http://ejournal.unikama.ac.id/index.php/JPPI 